\title{
The Complex Viral Etiology of St. Augustine Decline
}

Over Cabrera and Karen-Beth G. Scholthof, Department of Plant Pathology and Microbiology, Texas A\&M University, College Station 77843

\begin{abstract}
Cabrera, O., and Scholthof, K.-B. G. 1999. The complex viral etiology of St. Augustine decline. Plant Dis. 83:902-904.

St. Augustine decline is a viral disease of St. Augustinegrass, a turfgrass grown in the Gulf Coast region of the United States. Analyses of 204 plants in two locations in southeast Texas indicate that the disease is caused by an infection with panicum mosaic virus (PMV), alone or in any combination with satellite panicum mosaic virus (SPMV) and/or its satellite RNAs (satRNAs). This is the first report of the incidence of PMV satRNAs in field samples of St. Augustinegrass. Leaf symptoms of plants collected from the field ranged from severe bleaching to a mild chlorotic mottle, but after 5 months in the greenhouse, the plants had a relatively homogeneous chlorotic mottle phenotype, suggesting that environmental conditions have a significant influence on the development of this disease.
\end{abstract}

Panicum mosaic virus (PMV) was first observed in 1953 on switch grass (Panicum virgatum) in Kansas, and in 1966 on St. Augustinegrass (Stenotaphrum secundatum) in Texas $(7,13)$. The St. Augustine decline strain of PMV on St. Augustinegrass has been reported in Louisiana, Arkansas, Mississippi, South Carolina, Texas, and Mexico (2-4,7). Other strains of PMV have been identified in centipede grass (Eremochloa ophiuroides) and St. Augustinegrass by serological assays with polyclonal antisera to purified virions (5). St. Augustine decline is characterized by a chlorotic mottle, and in some instances, an infected lawn may rapidly succumb to the infection due to necrosis of the leaves and stolons (7), whereas in other situations, the infection causes little damage to St. Augustinegrass $(3,5)$. There are no known biological vectors of PMV, but it is readily transmitted mechanically, including by contaminated lawn mower blades $(3,5)$. Vegetatively propagated turf is distributed as sod, which may also account for the widespread incidence of the disease (2).

PMV is a single-stranded positive-sense RNA (ssRNA) virus of 4,326 nucleotides (nt) that is encapsidated into $30-\mathrm{nm}$ icosahedral particles by its $26-\mathrm{kDa}$ capsid protein $(\mathrm{CP})(1,14)$. The virus has been assigned as the type member of a new genus Panicovirus within the Tombusviridae (14). PMV is capable of supporting the replication of two types of satellites, a satellite virus (SPMV) and satellite RNAs (satRNAs).

Corresponding author: Karen-Beth G. Scholthof E-mail:kbgs@acs.tamu.edu

Accepted for publication 10 June 1999.

Publication no. D-1999-0709-02R

(C) 1999 The American Phytopathological Society
SPMV contains an 824-nt ssRNA that encodes a 17.5-kDa CP to form 16-nm icosahedral virions $(1,6)$. Mixed infections of SPMV with PMV have been reported in switch grass, centipede grass, and St. Augustinegrass $(1,9)$. PMV satRNAs are approximately 375-nt ssRNAs that do not encode any known proteins (8).

The etiology of St. Augustine decline is not well defined. Earlier studies confirmed the presence of PMV in St. Augustinegrass, but the role and prevalence of SPMV and satRNAs have not been determined. The intent of this survey was to define the etiology of St. Augustine decline based on the incidence of PMV, SPMV, and the satRNAs in southeastern Texas. Greenhouse studies also allowed for an assessment of the role of these infectious RNAs in the development of the symptom phenotypes characteristic of St. Augustine decline.

\section{MATERIALS AND METHODS}

Sample collection. College Station and Corpus Christi, Texas, are approximately $350 \mathrm{~km}$ apart and were chosen as collection sites to determine geographic differences in the profiles of PMV, SPMV, and satRNAs in St. Augustinegrass plants. At each location, 102 plants with a range of symptoms were collected. To ensure that the survey was representative of both areas, multiple symptomatic plants were rarely collected from the same yard or park. A sprig from each plant was transplanted to an 8-cm pot filled with a soil mixture of Bactomix and sand (90:10 vol/vol) with Osmocote fertilizer added as needed. Fifteen asymptomatic St. Augustinegrass plants also were collected from College Station to confirm that symptoms were a reliable characteristic for identification of infected plants.

Molecular characterization. Routine molecular biology protocols (10) were followed to detect the proteins and/or RNAs associated with St. Augustine decline. Primary assays were conducted on leaves from the field samples; for subsequent testing and confirmation, we used the transplanted sprigs from the same material. Total proteins were extracted by grinding $100 \mathrm{mg}$ of leaf tissue in liquid nitrogen, followed by the addition of 500 $\mu \mathrm{l}$ of TE buffer (10 mM Tris, $1 \mathrm{mM}$ EDTA, $\mathrm{pH}$ 8.0). This mixture was vortexed for a few seconds and then centrifuged at $10 \mathrm{~K} \times$ $g$ for $10 \mathrm{~min}$ at $4^{\circ} \mathrm{C}$. The clear supernatant $(100 \mu \mathrm{l})$ was mixed with $100 \mu \mathrm{l}$ of sample buffer (1.3 M Tris, pH 6.8, 5\% sodium dodecyl sulfate [SDS], 5\% $\beta$-mercaptoethanol, 5\% bromophenol blue, and 50\% glycerol), boiled for $5 \mathrm{~min}$, and centrifuged. Proteins were separated on $12.5 \%$ SDS-polyacrylamide gel by electrophoresis and transferred to a nitrocellulose membrane. Immunoblot analyses were performed with polyclonal antibodies specific against PMV and SPMV coat proteins at a dilution of 1:2,000, as described previously (12).

Extraction of total nucleic acids from $200 \mathrm{mg}$ of leaf tissue and agarose gel electrophoresis were carried out according to previously described protocols (11). Radioactive ${ }^{32} \mathrm{P}$ dCTP-labeled random primed probes specific for PMV, SPMV, or the satRNA were used to individually detect each of the RNAs on triplicate nylon membranes. The RNA blots were hybridized in $2 \times$ SSPE $(150 \mathrm{mM} \mathrm{NaCl}, 2 \mathrm{mM}$ $\mathrm{Na}_{2}$ EDTA, and $10 \mathrm{mM} \mathrm{NaH} \mathrm{PO}_{4}, \mathrm{pH} 7.4$ ) $+1 \%$ SDS overnight, washed twice for 15 min at room temperature with $2 \times$ SSPE and $0.1 \%$ SDS, and developed by autoradiography (10).

\section{RESULTS}

Initial northern (RNA) blot assays revealed a strict correlation between symptoms and the presence of PMV, and in many instances these plants were coinfected with SPMV and/or satRNAs (Fig. 1). Fifteen symptomless plants from College Station were free of PMV (data not shown). Based on these observations, the survey was expanded to include more samples from College Station and an additional survey location at Corpus Christi. Of the 204 plants with characteristic symptoms of St. Augustine decline, all were shown to be infected with PMV, 61\% (125 plants) harbored satRNAs, and 77\% (158 plants) were positive for SPMV RNAs. A correlation between the type of infection and the symptom phenotype of the plants was not obvious. 
There were differences in the distribution of PMV and its satellites between the College Station and Corpus Christi collection sites. In the College Station area, all of the 102 plants were infected with PMV, but only $21 \%$ were infected with PMV alone. The majority of the plants (79\%) supported a mixed infection of PMV with SPMV and/or satRNAs (Fig. 2). In total, $72 \%$ of the plants were coinfected with SPMV, representing infection combinations of PMV + SPMV (45\%) or PMV + SPMV + satRNA $(27 \%)$. The least common combination in this area was a mixture of PMV + satRNA (7\%) (Fig. 2).

In the Corpus Christi area, PMV as a single infection or with satRNA was detected in only 3 and $1 \%$ of the collected plants, respectively, because virtually all (96\%) of the plants were also coinfected with SPMV (Fig. 2). This could be further defined as infections with PMV + SPMV or PMV + SPMV + satRNA in 53 and $43 \%$ of the samples, respectively. As was the case in College Station, the PMV and SPMV RNA blots from the Corpus Christi area were in agreement with the PMV CP and SPMV CP immunoblot assays (data not shown).

St. Augustinegrass is stoloniferous, which permits the plant to spread along the ground surface as stems that can root at the nodes. This feature allowed us to propagate sprigs from the collected plants for transplants and subsequent long-term observation in the greenhouse. Initially, the plants displayed a range of leaf symptoms from a mild mottle to bleaching. After 5 months of growth in the greenhouse, under uniform environmental and nutritional conditions, the symptoms became more generalized as a chlorotic mottle. This

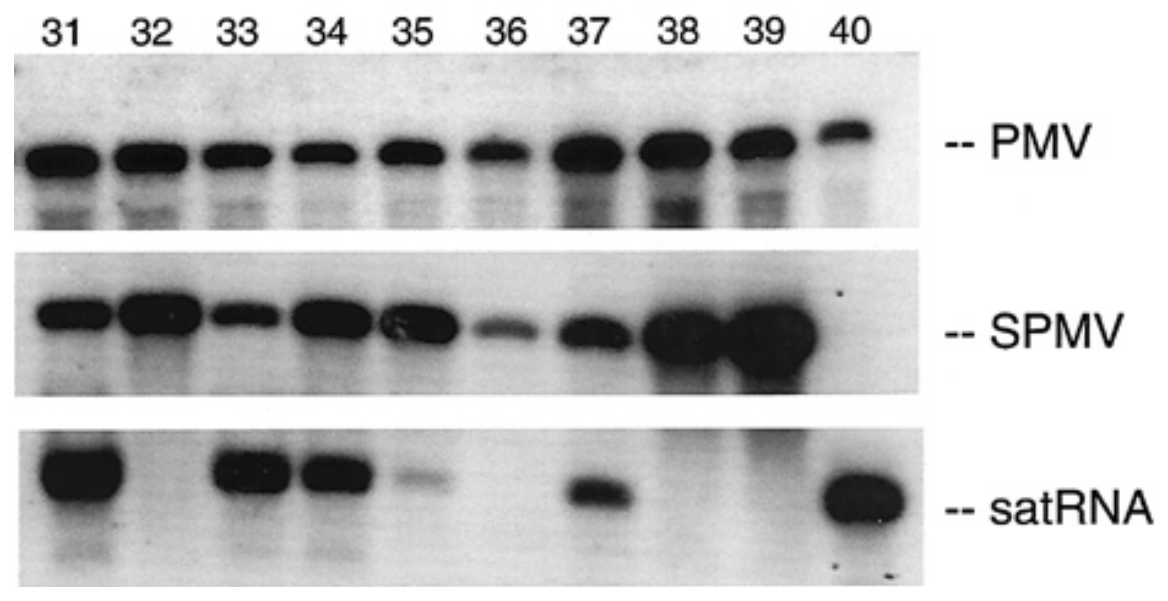

Fig. 1. Representative RNA blot to detect the incidence of panicum mosaic virus (PMV), satellite panicum mosaic virus (SPMV), and satellite RNA (satRNA) in symptomatic plants from College Station, Texas. Total RNA was extracted from St. Augustinegrass plants, electrophoresed through $1.5 \%$ agarose gels, and transferred to nylon membrane. The blots were run in triplicate to allow for probing with ${ }^{32} \mathrm{P}$-labeled cDNAs to specifically identify their RNAs, as indicated at the right of each blot. Sample numbers are indicated above lanes.

\section{College Station}

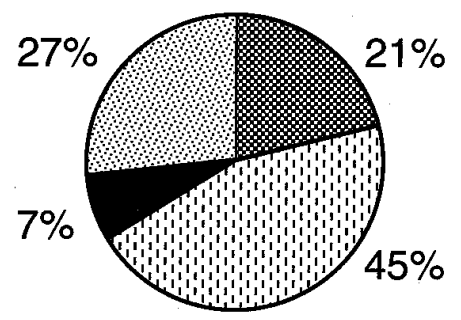

PMV+SPMV+satRNA

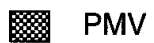

\section{Corpus Christi}

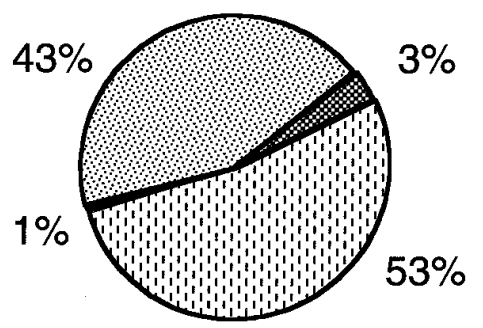

PMV+satRNA

PMV+SPMV

Fig. 2. Analyses of components associated with St. Augustine decline in 204 symptomatic St. Augustinegrass plants collected at College Station and Corpus Christi, Texas. Plants were analyzed for the capsid proteins encoded by panicum mosaic virus (PMV) and satellite panicum mosaic virus (SPMV), as well as the genomic RNAs of PMV, SPMV, and satellite RNAs (satRNA). Each collected site represents 102 samples.

observation suggests that environmental conditions significantly affect symptoms. Based on symptoms alone, it was not possible to distinguish which combinations of SPMV and/or satRNAs were present in infected St. Augustinegrass plants.

\section{DISCUSSION}

This study on St. Augustine decline disease revealed that the majority of PMVinfected plants harbored SPMV and/or satRNAs (Figs. 1 and 2), but there was no relationship between the type of infection and symptom phenotype in the field or greenhouse. Even though the symptoms observed in this evaluation were often very mild, the disease could easily be distinguished from nutritional disorders or downy mildew (Sclerophthora macrospora) infections.

SPMV has been identified in forage grasses in the Great Plains states and in St. Augustinegrass in the Gulf Coast states, but its origin and the mechanism of its distribution are unknown. Since satRNAs are not uncommon in plant virus infections, it is not surprising to find them in association with PMV. The greater incidence of PMV alone (22\%) in College Station than in the more southern Corpus Christi area (4\%) prompts the idea that a correlation may exist between the geographic location or environmental conditions and the presence of satellites (SPMV or satRNA), but this needs to be determined in future investigations.

Different serological strains of PMV $(3,5)$ and variants of the satellites may have a role in the progression of disease. Wild or cultivated grasses that serve as reservoirs for PMV (as well as for SPMV and/or satRNA) may also have a role in the introduction and proliferation of new virus strains on St. Augustinegrass. The effects may vary on different cultivars of the host plant, resulting in somewhat variable disease phenotypes. In addition, our results show that the severity of the St. Augustine decline phenotype, represented by PMV alone or as mixtures with its satellites, is affected by light, temperature, and/or nutrient conditions. This confirms and extends the observations of Holcomb et al. (5), who reported that the symptoms elicited by PMV or PMV + SPMV were indistinguishable in the greenhouse even when there had been significantly different phenotypes in the lawn. Our RNA hybridization data (Fig. 1) add to this, showing that PMV satRNAs are also widely distributed. The combined results imply that St. Augustine decline is the end result of a set of complex and multifaceted interactions.

Perhaps the best strategy to dissect St. Augustine decline is to invoke the phytopathological concept of the disease triangle, i.e., the interactions between the host plant, the pathogen (PMV, SPMV, and satRNAs), and the environmental conditions that have converged to sustain this 
well-established disease. There is little information related to St. Augustinegrass cultivars, which are presently identified by agronomic characteristics. Since some cultivars may be better hosts for PMV (and satellite) infections, it will be necessary to develop molecular markers for cultivar typing of St. Augustinegrass to investigate these interactions. For related purposes, we are in the process of analyzing the genetic variability of the satRNAs from these St. Augustinegrass plants. There are many avenues to explore regarding the ecology and evolution of this disease on turf and forage grasses. A better understanding of the interactions between the host and the pathogen (PMV, SPMV, and the satRNAs), two necessary components of the disease triangle, may provide new strategies for disease control that are effective under a wide array of environmental conditions.

\section{ACKNOWLEDGMENTS}

We thank Marilyn Roossinck, Joseph Krausz, and Mark Hussey for helpful discussions on sample collection and data analyses. We also appreciate the technical and greenhouse assistance provided by Beth Whitehead and critical comments and suggestions for the manuscript provided by WenPing Qiu, Herman Scholthof, Jeff Batten, and Marilyn Roossinck. Funding for the research was provided by the S. R. Noble Foundation, Ardmore, OK, the Texas Agricultural Experiment Station (H-8388), and USDA Competitive Grant 9635303-3714.

\section{LITERATURE CITED}

1. Buzen, F. G., Jr., Niblett, C. L., Hooper, G. R., Hubbard, J., and Newman, M. A. 1984. Further characterization of panicum mosaic virus and its associated satellite virus. Phytopathology 74:313-318.

2. Dale, J. L., and McDaniel, M. C. 1982. St. Augustinegrass decline in Arkansas. Plant Dis. 66:259-260.

3. Haygood, R. A., and Barnett, O. W. 1992. Widespread occurrence of centipedegrass mosaic in South Carolina. Plant Dis. 76:46-49.

4. Holcomb, G. E., Derrick, K. S., Carver, R. B., and Toler, R. W. 1972. St. Augustine decline virus found in Louisiana. Plant Dis. Rep. 56:69-70.

5. Holcomb, G. E., Liu, T.-Y. Z., and Derrick, K S. 1989. Comparison of isolates of panicum mosaic virus from St. Augustinegrass and centipedegrass. Plant Dis. 73:355-358.

6. Masuta, C., Zuidema, D., Hunter, B. G., Heaton, L. A., Sopher, D. S., and Jackson, A. O. 1987. Analysis of the genome of satellite panicum mosaic virus. Virology 159:329-338.
7. McCoy, N. L., Toler, R. W., and Amador, J. 1969. St. Augustine decline (SAD)-A virus disease of St. Augustine grass. Plant Dis. Rep. 53:955-958.

8. Monis, J., Sopher, D. S., and Jackson, A. O. 1992. Biologically active cDNA clones of panicum mosaic virus satellites. Phytopathology $82: 1175$.

9. Niblett, C. L., and Paulsen, A. Q. 1975. Purification and further characterization of panicum mosaic virus. Phytopathology 65:1157-1160.

10. Sambrook, J., Fritsch, E. F. and Maniatis, T 1989. Molecular Cloning: A Laboratory Manual. Cold Spring Harbor Laboratory, Cold Spring Harbor, NY.

11. Scholthof, H. B., Morris, T. J., and Jackson, A. O. 1993. The capsid protein gene of tomato bushy stunt virus is dispensable for systemic movement and can be replaced for localized expression of foreign genes. Mol. Plant-Microbe Interact. 6:309-322.

12. Scholthof, K.-B. G. 1999. A synergism induced by satellite panicum mosaic virus. Mol. Plant-Microbe Interact. 12:163-166.

13. Sill, W. H., and Pickett, R. C. 1957. A new virus disease of switchgrass, Panicum virgatum L. Plant Dis. Rep. 41:241-249.

14. Turina, M., Maruoka, M., Monis, J., Jackson, A. O., and Scholthof, K.-B. G. 1998. Nucleotide sequence and infectivity of a full-length cDNA clone of panicum mosaic virus. Virology 241:141-155. 